\title{
AN AGRO-ECOLOGICAL SIMULATION MODEL SYSTEM
}

\author{
M. LADÁNYI* - L. HoRVÁtH - M. GAÁL - L. HuFNAGEL \\ *e-mail:mladanyi@kee.hu \\ Department of Mathematics and Informatics, Faculty of Horticultural Sciences, \\ Szent István University, H-1118 Budapest, Villányi út 29-33, Hungary \\ (phone: +36-1-372-6261; fax: +36-1-466-9273) \\ (Received $15^{\text {th }}$ April 2002; accepted $15^{\text {th }}$ June 2003)
}

\begin{abstract}
In this paper five different models, as five modules of a complex agro-ecosystem are investigated. The water and nutrient flow in soil is simulated by the nutrient-in-soil model while the biomass change according to the seasonal weather aspects, the nutrient content of soil and the biotic interactions amongst the other terms of the food web are simulated by the food web population dynamical model that is constructed for a piece of homogeneous field. The food web model is based on the nutrientin-soil model and on the activity function evaluator model that expresses the effect of temperature. The numbers of individuals in all phenological phases of the different populations are given by the phenology model. The food web model is extended to an inhomogeneous piece of field by the spatial extension model. Finally, as an additional module, an application of the above models for multivariate state-planes, is given. The modules built into the system are closely connected to each other as they utilize each other's outputs, nevertheless, they work separately, too. Some case studies are analysed and a summarized outlook is given.
\end{abstract}

Keywords: food web, population dynamical model, activity function, spatio-temporal simulation model, multivariate state-planes

\section{Introduction}

The need to apply computer science and electronics in agricultural production for a targeted region has become increasingly urgent. By 'precision and sustainable agriculture', we mean not only a new production method, but also a complex system that

- integrates biological, technological and economic factors, and

- joins the natural circumstances flexibly.

This form of agriculture aims to optimize proficiency and environmental protection, by assessing together forecasts for risk, damages and profit.

In order to get to know better how the examined agro-ecosystem is functioning, we need correct simulation models of the complex food web system, as well as continuous monitoring of the processes [24, 31, 32, 37].

This simplified food web model accounts for seasonal weather aspects [74, 75], the nutrient content of soil and biotic interactions (Fig. 1). On the first level, $K$ denotes the water and nutrient content of soil, as the input of the system. The input comes from a simplified nutrient-in-soil model [54] described below. Above the nutrient-in-soil term $K$, are cultivated plants, denoted by $N$, and two kinds of weed, denoted by $G_{1}$ and $G_{2}$, respectively. On the third level, monophagous $M_{1}$ consumes the cultivated plant $N$, while monophagous $M_{2}$ eats one of the weeds. $P$ denotes a polyphagous pest which consumes the cultivated plant $N$, as well as weed $G_{l}$. Additionally, there is a predator, denoted by $P$, that consumes pests $M_{1}, P$ and $M_{2}$. 


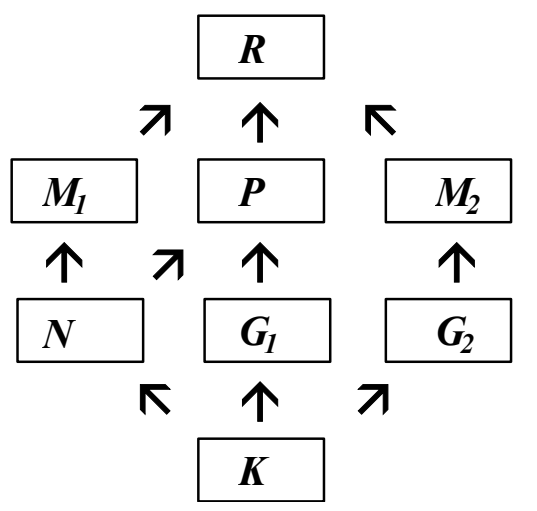

Figure 1. A food web model. The interactions amongst nutrient-in-soil (K), cultivated plant $(N)$, weeds $\left(G_{1}\right.$ and $\left.G_{2}\right)$, monophagous $\left(M_{1}\right.$ and $\left.M_{2}\right)$ and polyphagous $(P)$ pests, as well as predator $(R)$. (The arrows run from the nutrient to the consumer.)

In this paper five different models, as five modules of a complex agro-ecosystem are investigated, furthermore, an extra module is constructed:

- The water and nutrient flow in soil is simulated by the nutrient-in-soil model.

- The biomass changes according to the seasonal weather aspects, the nutrient content of soil and the biotic interactions amongst the other terms of the food web, are simulated by the food web population dynamical model. The model is constructed specially for a piece of homogeneous field.

- The activity function evaluator model expresses the effect of the daily average temperature on the activity of the individuals.

- The numbers of individuals in all phenological phases of the different populations are given by the phenology model.

- The food web model is extended for a piece of inhomogeneous field by the spatial extension model.

- The last module gives an application of the above models for multivariate stateplanes.

Although the modules built into the system are working separately, too, they are closely connected to each other, as they can utilize each other's outputs:

- The food web model is based on the activity function evaluator model and on the nutrient-in-soil model and it can immediately be followed by the phenology model.

- The nutrient-in-soil model applies the outputs of the food web model as its own inputs.

- The food web model and the spatial extension model can directly be linked.

- The multivariate state-planes module is built on the results of the food web model completed with the phenology model and on the ones of the spatial extension model.

To simulate the interactions, a discrete difference equation system with daily scale is used. As in the literature, there are plenty of excellent models which describe certain parts of the processes quite exactly, our aim was to create a model that describes the whole interaction process, in order to be able to apply it also in cases when detailed data are missing and to extend it in cases when more complex data are available.

The pattern analysis and the investigation of spatio-temporal inhomogeneity of agricultural fields are also of great significance, especially in the precision and 
sustainable agriculture. Additionally, it is important to elaborate the methodology of the information and data handling and the optimal decision making. Our aim is to go ahead in these problems. In former works the agro-ecosystem models (soil-plant-weatherpest systems) and pattern analyses were operated separately. By a spatial extension of the agro-ecosystem model a space specific complex ecological model is obtained.

Some case studies are analysed and a summarized outlook, amongst others, of possible ways to develop and apply the models, is given.

\section{Review of literature}

After the first food web model was described by Shelford in 1913, the most popular early monography became Bird's book from 1930 (In Jordán, [42]). Since that time, several theories have been appeared investigating the food web from several different points of view such as from energetical aspect [56], from population dynamical aspect [41], from stability, graph theory or information theory aspects $[69,70,81,82]$. The structure of a food web and its interactions are characterized by Jordán [42, 44], while its reliability has been investigated by Jordán and Molnár, 1999; Jordán et al, 1999; Jordán, 2000 [43, 45, 46]. In the past, there have been few papers published on foodweb researches applied for Hungary.

Models have been constructed for ecosystems with food web simulations [65] that, nevertheless, are based on classical Lotka-Volterra interactions, ignoring either abiotic effects or phenological aspects. Crop-weed competition is investigated e.g. in Kropff and Laar [50] and a population-phenology simulator is applied by Mols [60, 61].

Agricultural modelling and empirical survey deal mainly with soil-plant-weather systems with different additional main points, such as climate change impact studies $[10,58]$, mineralisation and heat, water and nitrate transfer [18], soil heat and water dynamics

$[27,79]$, non-homogeneous cropped soil profile [47, 64], management impact [27, 77], environmental conditions [51, 62], water and nutrient dynamics in a plant [68], fertilization [14], physiological and physical processes [8], water run-off and erosion in soil [49], phenology [48], planning and decision support [2, 3, 8], cropping systems [77] and informatics $[19,20,21]$. Investigations of food web sytems are, however, not involved in the above studies. Comparisons of cropping systems can be found in Francaviglia and Marchetti [17] and in Giardini et al. [25]. A valuable review of methodologies to evaluate simulation models is given by Martorana and Bellocchi [59].

There have been published some recent papers on zoocoenological explorations of fresh-water patterns $[4,12,13,36,81]$. Investigations on agro-ecosystems can be found in Hufnagel et al. [32], in Ferenczy et al. [16] and in Nyilas et al. [64] for pest populations. Methodological questions of the ecosystem surveys are discussed e.g. in Hufnagel et al. [33, 34, 35] and in Gaál and Hufnagel [22, 23, 24], while the ones for agrosystem researches can be found in Harnos [28].

\section{Results}

\section{Water and nutrient flow in soil}

In order to minimize the difference between the optimal and the real results in agriculture, water and nutrient flow in soil have been observed yet from several aspects $[5,9,83]$. There was created a special, drastically simplified nutrient-in-soil model by 
Erdélyi [15], with the special aim that it can be built into the food web population dynamical model to complete it with the most important abiotic effects.

The differential equation system of the nutrient-in-soil model consists of three equations: they follow the change of water, ionic nutrient and organic matter.

\section{Water content of soil}

As the plants can absorb ionic nutrient solution only, water content of soil plays as important role in vital processes as the ionic nutrient content of soil. The water content of soil is

- reduced mainly by evaporation (of soil and plant), by take-up and water run-off;

- increased mainly by the precipitation and watering.

These factors are depending, amongst others, on temperature, global radiation, the relative water holding capacity and the growing rate of the plant, as well as the water holding capacity and the current water content of the soil. These effects are involved in our model, nevertheless, other properties of soil such as the amount of carbon dioxide, the effect of wind, etc. are ignored.

Water content of soil $V_{t+1}$ at the $(t+1)^{\text {th }}$ point of time can be calculated with the help of the water content of soil $V_{t}$ at the $t^{\text {th }}$ point of time multiplied by an evaporation term $\Pi_{t}$, a take-up term $\Omega_{t}$ and, moreover, added to a precipitation - watering - and water run-off term $\Psi_{t}$ :

$$
V_{t+1}=V_{t} \cdot \Pi_{t} \cdot \Omega_{t}+\Psi_{t} .
$$

Evaporation term $\Pi_{t}$ is derived from the potential evapotranspiration formula due to Turc (in: Szász, [79]), that is given for the case water content is not limited and is corrected for the case water content does be limited which is the real case in Hungary. Evaporation term $\Pi_{t}$ is depending on the daily temperature, the daily global radiation value and the current water content of soil. The more the water content is, the greater the rate of evaporation is, thus the less the evaporation term $\Pi_{t}$ is; $0<\Pi_{t}<1$, and it is tending to 1 as the water content tends to zero.

Take-up term $\Omega_{t}$ is depending on the daily biomass growth $d B_{t}$ and on the relative water holding capacity of the plant. The more the daily growth $d B_{t}$ of the biomass is, the less take-up term $\Omega_{t}$ is and with $d B_{t} \rightarrow 0$, take-up term $\Omega_{t}$ tends to 1 .

Precipitation - watering - and water run-off term $\Psi_{t}$ is depending on the daily precipitation, the daily amount of watering and the water holding capacity of soil.

\section{Ionic nutrient and organic matter content of soil}

Denote by $K_{t}$ the daily ionic nutrient solution content of soil that depends, of course, on the daily water content of soil $V_{t}$. Ionic nutrient solution content of soil $K_{t+1}$ at the $(t+1)^{\text {th }}$ point of time can be calculated by ionic nutrient solution content of soil $K_{t}$ at the $t^{\text {th }}$ point of time multiplied by a take-up term $I_{t}$, an erosion term $E_{t}$, and added to a decomposition term $D_{t}$ and an artificial fertilizer term $K_{\text {art }, t}$ :

$$
K_{t+1}=K_{t} I_{t} E_{t}+D_{t}+K_{a r t, t} .
$$


Take-up term $I_{t}\left(0<I_{t}<1\right)$ is depending on the relative nutrient content of the plant derived from its need for ionic nutrient and on the daily biomass growth $d B_{t}$. It is obvious that the more the daily biomass growth $d B_{t}$ is, the less take-up term $I_{t}$ is, and as the daily biomass growth $d B_{t}$ tends to zero, take-up term $I_{t}$ goes to 1 .

Erosion term $E_{t}\left(0<E_{t}<1\right)$ expresses the fact that in case water is limited in soil, ionic nutrient solution is also limited by it, while in case water is unlimited, ionic nutrient solution is limited by ionic nutrient that is unable to be taken up by the plant. Erosion term $E_{t}$ depends on the solubility of the different kinds of ionic nutrient. The greater amount of ionic nutrient is erosed the less amount of it is erosable, so erosion term $E_{t}$ tends to 1 .

Organic decomposition term at the $t^{\text {th }}$ point of time $D_{t}$ can be expressed by the formula

$$
D_{t+1}=(1-\xi) D_{t}+D_{\text {biom }, t}+D_{o f, t},
$$

where $\xi<1$ denotes the daily percent of the decomposed organic matter, $D_{\text {biom }, t}$ denotes the amount of the developed organic matter in soil and $D_{o f, t}$ denotes the amount of utilizable organic fertilizer added.

The artificial fertilizer term $K_{a r t, t}$ is equal to the amount of the utilizable artificial fertilizer added.

\section{A food web seasonal population dynamical model}

An agro-ecosystem is directed mainly by the interactions amongst the populations living in the agro-ecosystem together. Several indirect or hidden types of interactions that can not be expressed as different kinds of material flow such as competition, the indirect interactions that can be derived from the escape from or the defence against a common predator, as well as the so-called 'top down and bottom up regulations' are involved in our food web population dynamical model. To simulate the interactions, a discrete difference equation system is used. The general equation of the web model is based on three elements: the first one is to express the activity of the individual depending on the temperature, the second one is to describe the effect of the quality and the quantity of nutrient of plants and/or pests and the third one is to display the effect of the predators. The model is based on the nutrient-in-soil model defined above.

To describe the interactions in the food web a discrete difference equation system with seven equations is used, each equation is for a certain element $N, G_{1}, G_{2}, M_{1}, M_{2}$, $P$, or $R$ of the system at the $(t+1)^{\text {th }}$ point of time. The general form of the difference equation is

$$
X_{t+1}=X_{t} \cdot R_{X, t} \cdot F_{X, t} \cdot P_{X, t},
$$

where

- the current amount of the biomass of one of the populations $N, G_{1}, G_{2}, M_{1}, M_{2}$, $P$, or $R$ at the $(t+1)^{\text {th }}$ and at the $t^{\text {th }}$ points of time are denoted by $X_{t+1}$ and $X_{t}$, respectively; 
- the activity term of the individual $X$ is denoted by $R_{X, t}$ and is depending on the daily average temperature $T$;

- $\quad F_{X, t}$ denotes the so-called nutrient term;

- $\quad P_{X, t}$ denotes the so-called predation term.

In what follows the terms of the general equation are characterized.

Activity term $R_{X, t}$

To forecast the time and the mass of the local appearance of pest generations, the socalled 'classical temperature-sum' method is widely used, however, it is often unreliable and in these cases the errors can rush quite high. To avoid this, a parametric activity function that uses the data of the National Light-trap Network and the daily average temperature data as input, has been created by a special optimisation process by Révész [73]. Our model is based on the idea that was applied by Révész, namely, the agroecological process for each individual $X$ is defined not by the temperature, itself, but by the so-called 'activity function' $r_{X}$ that is a non-linear function of the daily average temperature $T$ :

$$
\begin{gathered}
r_{X}: T \mapsto r_{X}(T)=\frac{1}{2}\left(\left|s_{X}(T)\right|+s_{X}(T)\right)^{f_{X}}, \\
s_{X}: T \mapsto s_{X}(T)=\frac{1}{\exp \left(a_{X}\left(T-b_{X}\right)\right)+\exp \left(-c_{X}\left(T-d_{X}\right)\right)}-\frac{1}{\exp \left(-a_{X} b_{X}\right)+\exp \left(c_{X} d_{X}\right)},
\end{gathered}
$$

where $a_{X}, b_{X}, c_{X}, d_{X}$ and $f_{X}$ are suitable constants relative to individual $X$.

Activity function $r_{X}$ expresses that the individuals do not develop under low temperature circumstances; while the temperature increases, the individuals develop at an increasingly rapid rate up to a certain point; at higher temperature as it is optimal for the individuals, the development is impeded peculiarly to the individuals' sensitivity.

Activity term $R_{X}$ is derived from the activity function $r_{X}$ by a linear transformation:

$$
R_{X}: T \mapsto A_{X} r_{X}(T)+B_{X} .
$$

The range of term $R_{X}$ is a narrow interval around number 1:

- In the case the temperature is unfavourable, $R_{X}<1$, the effect of the term is impedimental.

- In the case the temperature is favourable, $R_{X}>1$, the effect of the term is supporting.

Term $R_{X}$ is continuous, monotonously increasing until the temperature is optimal and monotonously decreasing if the temperature is higher than it is optimal (Figs. 2 and $3)$. 


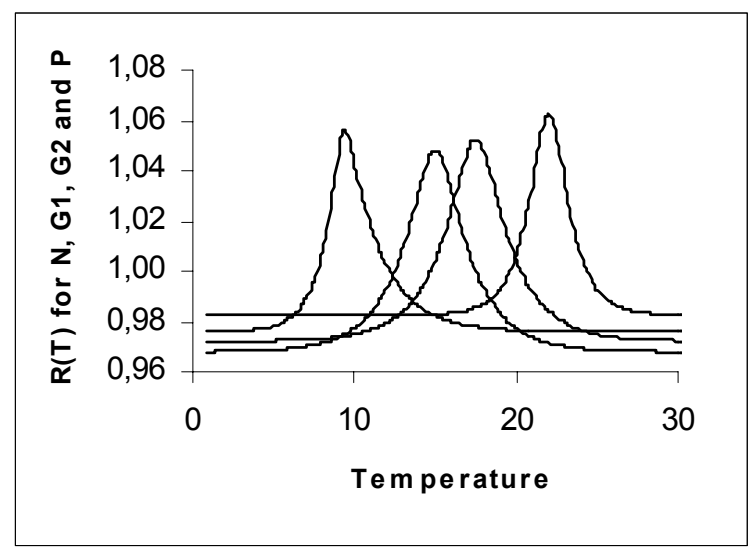

2

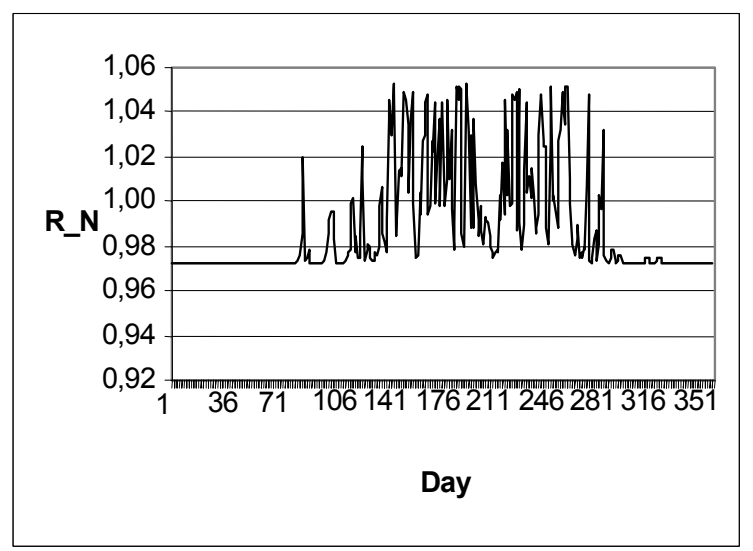

3

Figures 2-3. 2: Activity term of temperature $\left({ }^{\circ} \mathrm{C}\right)$ for the cultivated plant $N$, weeds $G_{1}$ and $G_{2}$ and polyphagous $P$. 3: Activity term of day for cultivated plant $N$.

Nutrient term $F_{X, t}$

Nutrient term $F_{X, t}$ is due to performance the following properties of the individuals in the model:

- In the case nutrient is unlimitedly available (under fixed all other circumstances), the biomass of $X$ is increasing at a maximal rate denoted by $\mathrm{K}_{\mathrm{X}}$.

- In the case nutrient is limited, the biomass of $X$ is increasing more slowly, stagnating or decreasing.

- In the case nutrient is just as much as needed, the amount of the biomass is nearly constant $\left(F_{X} \approx 1\right)$.

- In the case nutrient decreases excessively, the individual is going to die $\left(F_{X} \rightarrow 0\right)$.

- In the case the individual is in competition with another consumer, the change of biomass is influenced by the amount of the biomass of the other consumer together with some weight parameters.

- A polyphagous $(P$ or $R)$ consumes from the different populations in proportion to the amounts and the nutritive values of its nutrient-biomasses.

Term $F_{X}$ that satisfies all the properties above will be constructed step by step the following way. First, we give the proportion of the daily amount of total available nutrient reduced by the amount of necessary nutrient, and the amount of total available nutrient, more exactly the proportion $X_{F}$

\section{$(-1) \cdot($ total available nutrient - necessary nutrient)} total available nutrient

as follows:

$$
N_{F}=G_{1_{F}}=G_{2_{F}}=-\frac{K-a_{K N} N-a_{K G_{1}} G_{1}-a_{K G_{2}} G_{2}}{K+\varepsilon},
$$




$$
\begin{aligned}
& P_{F}=-\frac{N-a_{N M_{1}} M_{1}-a_{N P} \frac{P}{P+1} \cdot \frac{P}{N+\varepsilon} \cdot \frac{1}{G_{1}+1}+G_{1}-a_{G_{1} P} \frac{P}{P+1} \cdot \frac{P}{G_{1}+\varepsilon} \cdot \frac{1}{N+1}}{N+G_{1}+\varepsilon}, \\
& M_{1_{F}}=-\frac{N-a_{N M_{1}} M_{1}-a_{N P} \frac{P}{P+1} \cdot \frac{P}{N+\varepsilon} \cdot \frac{1}{G_{1}+1}}{N+\varepsilon} \\
& M_{2 F}=-\frac{G_{2}-a_{G_{2} M_{2}} M_{2}}{G_{2}+\varepsilon}, \\
& R_{F}=-\left(\frac{M_{1}-a_{M_{1} R} \frac{R}{R+1} \cdot \frac{R}{M_{1}+\varepsilon} \cdot \frac{1}{P+M_{2}+1}+P-a_{P R} \frac{R}{R+1} \cdot \frac{R}{P+\varepsilon} \cdot \frac{1}{M_{1}+M_{2}+1}}{P+M_{1}+M_{2}+\varepsilon}\right)+ \\
& -\left(\frac{M_{2}-a_{M_{2} R} \frac{R}{R+1} \cdot \frac{R}{M_{2}+\varepsilon} \cdot \frac{1}{P+M_{1}+1}}{P+M_{1}+M_{2}+\varepsilon}\right)
\end{aligned}
$$

Coefficients $a_{X Y}$ denote the weights of the narrows runnung from population $X$ to $Y$, constant $\varepsilon>0$ is a tiny number due to avoid numerical errors during division. It is obvious, that $X_{F}>-1$.

As the next step we introduce function

$$
f: x \mapsto f(x)=\left(\frac{2}{2+x}\right)^{v}
$$

that - substituting $x$ by $X_{F}$ - satisfies all the properties above but the first one because its limit remains under $\mathrm{K}_{\mathrm{X}}$ even in case nutrient is unlimitedly available. Note that we choose $v>0$ such that $v<\ln \mathrm{K}_{\mathrm{X}} / \ln 2$ holds.

Consider function

$$
g: x \mapsto g(x)=\max \left\{\left(1-\frac{\mathrm{K}}{2^{v}}\right) x+1,1\right\}
$$




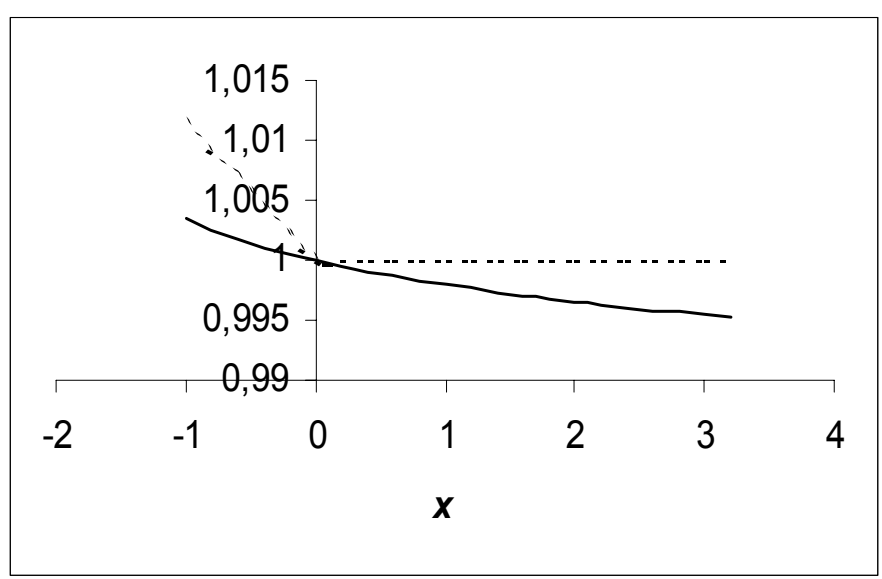

Figure 4. Functions $f$ (smooth line) and $g$ (dotted line).

that is linear, continuous, strictly monotonously decreasing whenever $x<0$ and takes constant 1 if $x \geq 0$.

Function

$$
F_{X}: X_{F} \mapsto F_{X}\left(X_{F}\right)=g\left(X_{F}\right) \cdot f\left(X_{F}\right)
$$

satisfies all the properties above including (i):

- If $-1<X_{F}<0$ that is to say, if nutrient is unlimitedly available:

$$
F_{X}: X_{F} \mapsto F_{X}\left(X_{F}\right)=\left\{\left(1-\frac{\mathrm{K}}{2^{v}}\right) X_{F}+1\right\} \cdot\left(\frac{2}{2+X_{F}}\right)^{v} \text {. }
$$

- If $X_{F} \rightarrow-1$ then $F_{X} \rightarrow \mathrm{K}$, so substituting $\mathrm{K}$ by $\mathrm{K}_{\mathrm{X}}$, we get that property (i) holds.

- If $X_{F} \geq 0$, that is to say, if nutrient is just enough or short

$$
F_{X}: X_{F} \mapsto F_{X}\left(X_{F}\right)=\left(\frac{2}{2+X_{F}}\right)^{v}
$$

so, in the case nutrient is just enough ( $X_{F} \approx 0$ ) then $F_{X} \approx 1$, thus (iii) is satisfied.

- Function $F_{X}$ is monotonously decreasing, thus (ii) holds.

- In case $X_{F} \rightarrow+\infty$, that is to say the individuals are starving, $F_{X} \rightarrow 0$, as a consequence, they are going to die, so (iv) holds.

- Property (v) follows from the construction of $X_{F}$, as we see that the decrease of the biomass of the nutrient-population is caused by the consumers-incompetition, together.

- Property (vi) follows from the construction of $X_{F}$, again, with the brake effects

$$
\frac{1}{G_{1}+1}, \frac{1}{N+1}, \frac{1}{P+M_{2}+1}, \frac{1}{M_{1}+M_{2}+1} \text { and } \frac{1}{P+M_{1}+1} .
$$




\section{Predation term $P_{X}$}

Predation term $P_{X}$ satisfies the properties of the biomass-change as follows:

- While the biomass of the consumer-population is increasing, the nutrientpopulation is decreasing at a slower and slower rate and, at the same time, the decreasing amount of the biomass of the nutrient-population is an impeding factor for the consumer-population. While the consumer-population is increasing slower, stagnating or decreasing, however, the amount of the biomass of the nutrient-population is going to stagnate or even to increase.

- Consider the case of polyphagy. From the one nutrient-population's aspect the effect of the other nutrient-population is, on the one hand, positive (while the other is being consumed, the one can escape), on the other hand, is negative (the other nutrient-population is making the consumer-population stronger by nourishing it).

The above effects of the interactions are quite complex. Our aim was to give the simplest model ever which describes the above properties as exactly as possible. It can be proved that terms

$$
\begin{gathered}
P_{N}=\frac{\left(1+a_{N P} \frac{P}{P+1} \cdot \frac{P}{N+\varepsilon} \cdot \frac{1}{G_{1}+1}+a_{N M_{1}} \frac{M_{1}}{M_{1}+1} \cdot \frac{M_{1}}{N+\varepsilon}\right)^{\mu}}{P_{G_{1}}=\frac{1}{\left(1+a_{G_{1} P} \frac{P}{P+1} \cdot \frac{P}{G_{1}+\varepsilon} \cdot \frac{1}{N+1}\right)^{\mu}}} \\
P_{M_{1}}=\frac{P_{G_{2}}=\frac{1}{\left(1+a_{G_{2} M_{2}} \frac{M_{2}}{M_{2}+1} \cdot \frac{M_{2}}{G_{2}+\varepsilon}\right)^{\mu}}}{\left(1+a_{M_{1} R} \frac{R}{R+1} \cdot \frac{R}{M_{1}+\varepsilon} \cdot \frac{1}{P+M_{2}+1}\right)^{\mu}} \\
P_{M_{2}}=\frac{1}{\left(1+a_{M_{2} R} \frac{R}{R+1} \cdot \frac{R}{M_{2}+\varepsilon} \cdot \frac{1}{P+M_{1}+1}\right)^{\mu}} \\
P_{P}=\frac{1}{\left(1+a_{P R} \frac{R}{R+1} \cdot \frac{R}{P+\varepsilon} \cdot \frac{1}{M+M_{2}+1}\right)^{\mu}}
\end{gathered}
$$

satisfy all the above properties where $\mu$ denotes a speed factor and $\varepsilon>0$ is a tiny number due to avoid numerical errors during division. 
Multipliers

$$
\frac{1}{G_{1}+1}, \frac{1}{N+1}, \frac{1}{M_{1}+M_{2}+1}, \frac{1}{P+M_{2}+1} \text { and } \frac{1}{P+M_{1}+1}
$$

are to express the breaking effect in case more predators are in competition. The other poperties can be derived in a similar way we did before for nutrient term $F_{X, t}$.

The connection of the nutrient-in-soil and the food web models

Input data applied by the models can be devided into four groups:

- Daily data such as precipitation, temperature, watering, global radiation, fertilization etc. These kinds of data have been available in Hungary for tens of years.

- Constants related to the plant, soil, ionic nutrient or speeds of bioprocesses etc. These kinds of data can be obtained by estimation or fitting.

- Staring values like $V_{0}, K_{0}, D_{0}$, etc. These kinds of data can be gained by e.g. soil survey.

- Other kinds of data such as the growth of biomass $d B_{t}$ defined by

$$
d B_{t}:=\max \left\{\sum_{\text {for all populations } X}\left(X_{t}-X_{t-1}\right), 0\right\},
$$

organic matter $D_{\text {biom }, t}$ developed in soil defined by

$$
D_{\text {biom }, t}=\left|\min \left\{\sum_{\text {for all populations } X}\left(X_{t}-X_{t-1}\right), 0\right\}\right|
$$

etc. that are the outputs of the food web model and inputs of the nutrient-in-soil model, on the other hand, the available nutrient in soil $K_{X, t}$ that is the output of the nutrient-in-soil model and the input of the food web model. It is realized such that one step is taken by the nutrient-in-soil model, its output would be input into the food web model, one step is taken by which right after. Having the output of the food web model, the nutrient-in-soil model can be started again.

\section{A case study for the population dynamical model.}

Simulated results based on daily average temperature and precipitation data measured in 1980, Debrecen, Hungary

The models described above was tested with real temperature and precipitation data together with fictious but real proportional starting values $K_{0}, V_{0}, S_{0}, N_{0}, G_{1,0}, G_{2,0}, M_{1,0}$, $M_{2,0}, P_{0}$, and $R_{0}$. The parameters of the activity terms as well as the coefficients $a_{i j}$ and the constant $\mathrm{K}_{\mathrm{X}}$ were set such that they can demonstrate the different temperature sensitivity and some other properties of the different populations. In Fig. 3, it can be seen that for the different populations, the advantageous effect of activity term $R_{X}>0$ appears at different points of time in spring and, furthermore, that at about the $220^{\text {th }}$ day of the year, there was a period with extremely high temperature and no precipitation, which was more or less impeding for every population. 

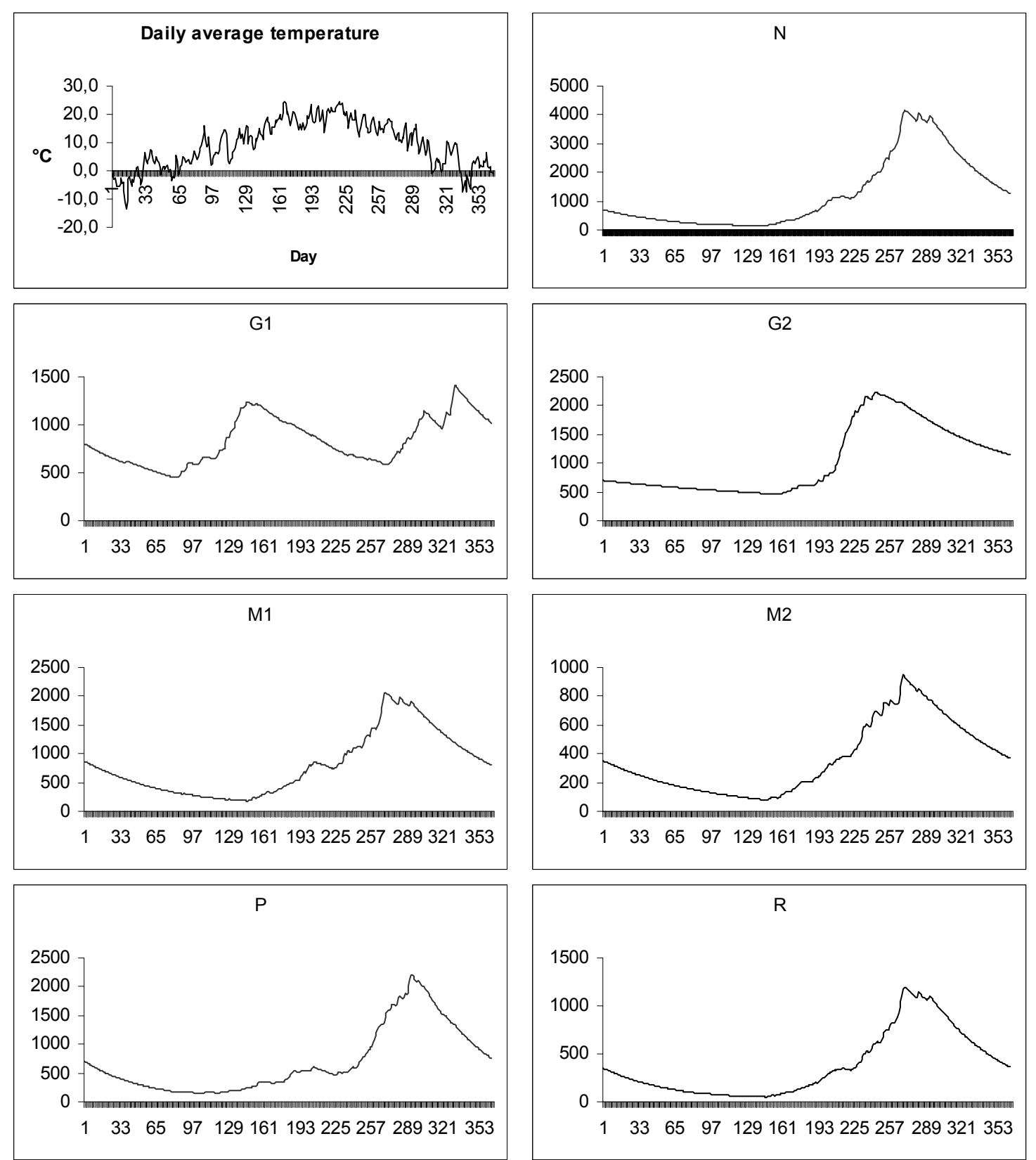

Figure 5. Biomass change of cultivated plant $N$, weeds $G_{1}$ and $G_{2}$, monophagous $M_{1}$ and $M_{2}$ and polyphagous $P$, as well as predator $R$; a simulated result based on the daily average temperature measured in 1980, Debrecen, Hungary. 
Compare temperature data with biomass data of the different populations in Fig. 5. (For the activity terms see Figs. 2 and 3.)

The biomass of cultivated plant $N$ (from the last year) had been slowly decreasing till spring, then after having reached its optimal daily average temperature (in June) it was acceleratingly increasing. The growth came to a point of standstill at about the $220^{\text {th }}$ day and after it reached its extended maximal rate, it was quickly decreasing.

Weed $G_{l}$ prefers low temperature. It started to increase quite early, rather intensively. In the middle of summer it was decreasing because of high temperature. After the average daily temparature fell below $15^{\circ} \mathrm{C}$, it increased again and started, again, to decrease quite late in autumn. In its graph, one can see the effect of fluctuating temperature in late autumn.

Weed $G_{2}$ prefers higher temperature. It started to grow very quickly earlier than cultivated plant $N$. After the $250^{\text {th }}$ day it was decreasing quite fast but the speed of decrease was lower and lower.

The activity term of monophagous $M_{l}$ is similar to the one of its nutriant, thus their biomass graphs are similar, too, just with a short time shift.

Monophagous $M_{2}$ consumes the weed that prefers higher temperature, though its optimal temperature is slightly lower. Therefore, it started to increase a bit later and slowlier than weed $G_{l}$ and the same is for its biomass decrease.

Polyphagous $P$ consumed from the early weed very few as it dislikes low temperature, however, it started to grow slowly. The decrease of the early weed left its mark on the graph of the pest. As the biomass of the cultivated plant started to increase quickly, the one of the polyphagous followed it and it started to decrease just after the cultivated plant's biomass subsided.

Predator $R$ can choose from three kinds of nutrient. It started to grow at about the $150^{\text {th }}$ day at a stable rate, it reached its extended maximum with the marks of fluctuating temperature in late autumn/early winter which is followed by a very quick decrease.

Simulated results based on the daily average temperature and precipitation data measured in 1980-84, Debrecen, Hungary

In Fig. 1, the seasonality relative to the populations can be seen well. While year 1983 was the most favourable for the cultivated plant $N$, yield in 1980 was quite poor (Fig. 6).

The effect of the mild winter in 1981-82 is considerable on the graph of the early weed $G_{l}$.

Besides seasonality, it can be seen in the graph of the weed $G_{2}$, which prefers warm weather, that the different conditions in different years imply graphs with different maximum, slope and convexity properties.

Notice the effect of a warmer (1981) and a cooler (1984) summer on monophagous $G_{l}$ that prefers warm weather.

The graph of monophagous $G_{2}$ that consumes the less sensitive weed seems to be the most stabile one.

Similarly to weed $G_{1}$, polyphagous $P$ prefers cool weather, thus years $1980-81$ were more favourable than the ones after.

The graph of predator $R$ can be said to be the less changeable. 

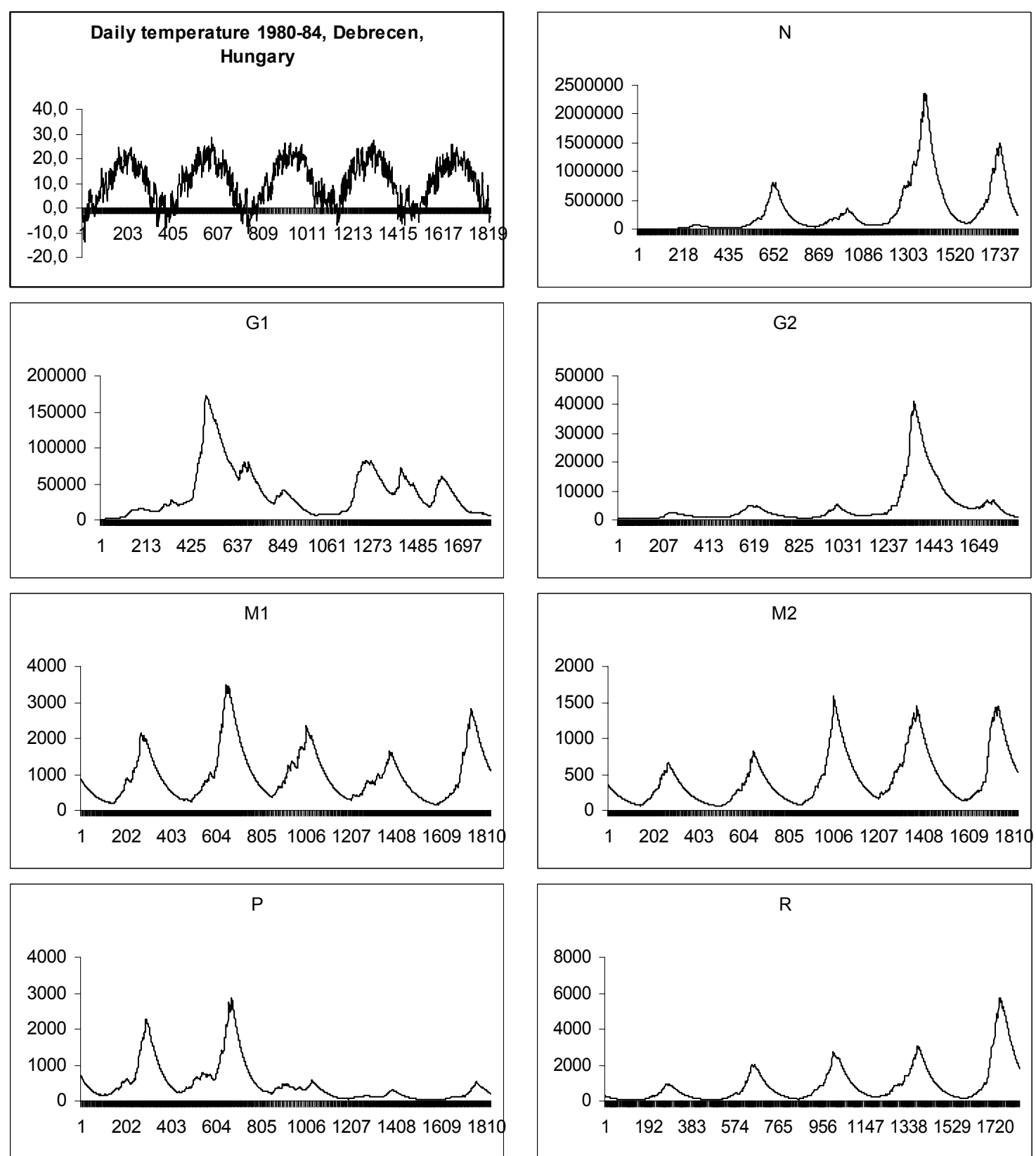

Figure 6. Five-year (1980-84) simulation results of the food web model for each element of the web. 


\section{Phenology model}

Applying the above models, the obvious question is how the number of individuals can be derived from a given amount of biomass. More exactly, if the phenological phases of the population, together with their biological properties, are known, how can one define the number of the individuals in the phases at a given point of time? The following model solves this problem.

Recall the idea mentioned in the section activity term $R_{X, t}$ was introduced, namely, that the agro-ecological process is not defined by temperature, itself, but by the socalled 'activity function', since the effect of the same temperature on the individuals is very different in different phenological phases. Thus, instead of cumulative temperature, we introduce cumulative activity

$$
\underset{t \geq t_{0, X}}{\operatorname{cum}} R_{X, t}^{P h}=\sum_{i=t_{0, X}}^{t} R_{X, i}^{P h} \cdot S W_{X, i}^{P h}
$$

with the help of which the entering dates of the phenological phases can be defined. Cumulative activity $\underset{t \geq t_{0, X}}{\operatorname{cum}} R_{X, t}^{P h}$ cumulates the values of activity terms $R_{X, t}^{P h}$ of individual $X$ from a starting point of time $t_{0, X}$ relative to $X$ (let us say 'the first spring point of $X$ '), in the case phase $P h$ holds, where $P h$ denotes one of $E_{i}$ (for the egg state of the $i^{\text {th }}$ generation,

$\left.i=1,2, \ldots, g_{X}\right), L_{j i}$ (for the $j^{\text {th }}$ larva state of the $i^{\text {th }}$ generation, $j=1,2, \ldots, l_{X}$ ) and $I_{i}$ (for the imago state of the $i^{\text {th }}$ generation).

To express the phase $P h$ holds we introduce function $S W_{X, t}^{P h}$ for a population of $X$ in a phenological phase $P h$ at a point of time $t$ :

$$
S W_{X, t}^{P h}:= \begin{cases}0 & \text { if } t=0 \text { and } P h>E_{1} \\ \prod_{P h>E_{1}}\left(1-S W_{X, t}^{P h}\right) & \text { if } P h=E_{1} \\ \min \left[\max \left\{\left(C u m R_{X, t}-T_{m, X}^{L_{1}}\right), 0\right\}, 1\right] \prod_{P h>L_{1}}\left(1-S W_{X, t}^{P h}\right) & \text { if } t>0 \text { and } P h=L_{11} \\ \min \left\{\min \left[\max \left\{\left(m_{X, t-1}^{P h}-k_{X}^{P h} \frac{m_{X}}{m_{X}}\right), 0\right\}, 1\right]+\min \left[\max \left\{\left(C u m R_{X, t}^{P h}-T_{m, X}^{P h_{1}}\right), 0\right\}, 1\right], 1\right\} * \\ * \prod_{P h>L_{1}}\left(1-S W_{X, t}^{P h}\right) & \text { if } t>0 \text { and } P h>L_{11}\end{cases}
$$

where

- $\quad T_{m, X}^{P h}$ denotes the minimum of cumulated activity of $X$ that is necessary to enter phase $P h$;

- $\quad m_{X, t}^{P h}$ denotes the current average mass of an individual $X$ in its state in phase $P h$;

- $\bar{m}_{X}$ denotes the average mass of an individual $X$ at entering phase $P h$;

- $g_{X}$ and $l_{X}$ denote the numbers of generations and larva phases related to $X$, respectively; 
- $\quad k_{X}^{P h}$ is a proportion constant $\bar{m}_{X}^{P h}$ is multiplied by which in order to obtain the maximum mass of an individual $X$ in phase $P h$ and, finally,

- relation $>$ for phases means, ,later phase than".

Function $S W_{X, t}^{P h}$ equals to 1 if and only if the population of $X$ has more than zero number of individuals in phase $P h$ at a given point of time $t$, and equals to 0 , else. The change of the values of function $S W_{X, t}^{P h}$

- from 0 to 1 is caused by the fact cumulated activity has reached the minimum that is necessary for an individual $X$ to enter phase $P h$ and/or by the one the mass of individual $X$ has reached the maximum an individual in phase $P h$ can even have;

- from 1 to 0 is caused by the fact the next phase has been entered.

With the help of function $S W_{X, t}^{P h}$, a corrected food web biomass model can be created as follows:

$$
X_{t+1}^{c o r r}=X_{t+1} \prod_{i=1}^{g}\left(1-S W_{X, t}^{E_{i}}\right)\left(1-S W_{X, t}^{I_{i}}\right)+W\left(X_{t}\right) \sum_{i=1}^{g} S W_{X, t}^{E_{i}}+I\left(X_{t}\right) \sum_{i=1}^{g} S W_{X, t}^{I_{i}}-L S_{X}^{P h} \chi_{X, t}^{P h} .
$$

The corrected food web biomass model above satisfies the following properties:

- In winter there is no growth; in this case, function $W$ of $X_{t}$ expresses the biomass-waste caused by winter weather.

- During the imago phase consumption is suspended; in this case, function $I$ is the same as $X_{t+1}$ of the original food web biomass model, except term $F_{X}$, which is now identically equal to 1 .

- There is a loss in biomass at entering a new phase; function $L S_{X}^{P h}$ of $X_{t}$ denotes the amount of it, with characteristic function $\chi_{X, t}^{P h}$, that is equal to 1 if and only if $t$ is the point of time phase $P h$ entered, and is equal to zero, else.

It is obvious that there must be a point of time a phase is entered first, and, at the same time, there must be another one at which the process of metamorphosis is finished for the whole population. This means that function $S W_{X, t}^{P h}$ that 'switches' on/off the phases has to be smoothed as follows:

$$
\begin{gathered}
S S W_{X, t}^{E_{1}}=S W_{X, t}^{E_{1}}+p_{X, t}^{L_{1}}, \\
S S W_{X, t}^{P h}=S W_{X, t}^{P h} *\left(1-p_{X, t}^{P h}\right)+p_{X, t}^{P h+1},
\end{gathered}
$$

where

$$
\begin{gathered}
p_{X, t}^{L_{1}}=\left\{1-\min \left[\max \left(\frac{c u m R_{X, t}^{L_{1}}-M T 1_{X}^{L_{1}}}{M T 2_{X}^{L_{1}}-M T 1_{X}^{L_{1}}}, 0\right), 1\right]\right\} \cdot S W_{X, t}^{L_{1}}, \\
p_{X, t}^{P h}=\left\{1-\min \left[\max \left(\frac{m_{X, t}^{P h}-c 1_{X}^{P h} \cdot \bar{m}_{X}^{P h}}{\left(c 2_{X}^{P h}-c 1_{X}^{P h}\right) \bar{m}_{X}^{P h}}, 0\right), 1\right]\right\} \cdot S W_{X, t}^{P h} \quad \text { for every } P h>L_{1} .
\end{gathered}
$$

This means that $p_{X, t}^{P h}$ is equal to zero until phase $P h$ is entered. In the case the minimal value of activity, that is necessary to enter phase $P h$ has been reached, it 
monotonously decreases from 1 to zero. At the point of time at which the whole process of metamorphosis is finished, $p_{X, t}^{P h}$ becomes to be equal to, and also keeps to be, zero.

It is easy to see that

$$
\sum_{\text {for all phases }} S S W_{X, t}^{P h}=1 .
$$

Finally, the numbers of individuals in all phases will be calculated as follows. Set out from an estimated starting value of the number of individuals at a starting point of time $t_{0}$ in phase $E_{1}$ :

$$
N o I_{X, t_{0}}^{E_{1}}=\frac{X_{t_{0}}}{\bar{m}_{X}^{E_{1}}},
$$

from which the numbers of individuals of later phases can be derived if $P h \neq E_{i}$ :

$$
N o I_{X, t}^{P h}=N o I_{X, t_{0}}^{P h-1} p_{X, t}^{P h}+\left[\min \left(\frac{X_{t}}{w_{X}^{P h} \cdot \bar{m}_{X}^{P h}}, N o I_{X, t-1}^{P h}\right) \chi_{X, t}^{s}+\min \left(\frac{X_{t}}{\bar{m}_{X}^{P h}}, N o I_{X, t-1}^{P h}\right)\left(1-\chi_{X, t}^{s}\right)\right] S S W_{X, t}^{P h}
$$

where $0 \leq \chi_{X, t}^{s} \leq 1$ denotes a function to express the rate of starving of a population of $X$ at a point of time $t$, calculated with the help of

- the available amount of nutrient (denoted by $N U_{X, t}^{a v}$ ), as well as

- the necessary amount of nutrient (denoted by $N U_{X, t}^{n e}$ ) as follows:

$$
\chi_{X, t}^{s}=\min \left(\frac{N U_{X, t}^{a v}}{N U_{X, t}^{n e}}, 1\right) .
$$

Constant $0<w_{X}^{P h}<1$ denotes the rate of maximum amount of weight that can be loosed without dying.

This formula is suitable to express the following properties of the populations:

- The sum of the numbers of individuals does not increase in any phase except if $P h=E_{i}$ for $i=1,2, \ldots, g_{X}$.

- During the metamorphosis from a phase $P h$ into the next one, denoted by $P h+1$, the number of individuals in phase $P h$ is decreasing tending to 0 , while the number of individuals in phase $P h+1$ is increasing.

- The decrease of the biomass of $X$ can be caused, on the one hand, by the fact that in case nutrient is short the individuals are losing their weights, and, on the other hand, by the one the population is consumed by another population. The number of individuals, in the first case, does not change, while, in the latter case, it is decreasing.

In case nutrient is shorter than it is necessary for the individuals even to keep being in existence, the number of individuals is decreasing because of starvation.

Note that the loss of biomass during the metamorphoses has been yet subtracted from the biomass of $X$.

The current average mass of an individual $X$ in a phase $P h$ at a point of time $t$ can be obtained as: 


$$
m_{X, t}^{P h}=\left\{\begin{array}{cl}
m_{X, t}^{P h}=\frac{X_{t}}{N o I_{X, t}^{P h}} & \text { if } P h \neq E_{i} \text { and } P h \neq I_{i} \\
m_{X, t}^{L_{j i}} & \text { if } P h=I_{i}, j=l_{X} \\
m_{X}^{E} & \text { else }
\end{array}\right.
$$

where $E$ is belonging to the same generation as $P h$. Therefore, the number of eggs of a later generation than the first one is

$$
N o I_{X, t}^{E_{i}}=\frac{d B_{X}^{L_{j i}}}{\bar{m}_{X}^{E_{i}}} \quad\left(i=2,3, \ldots, g_{X}, j=l_{X}\right),
$$

that is to say, the number of eggs can be derived from the whole biomass growth $d B_{X}^{L_{j i}}$ during the very last phase just before imago phase, which is, practically, equal to the biomass of eggs.

\section{The spatial extension model}

In what follows, a simplified spatial extension model of the above agro-ecosystem model, with the help of which a space specific complex ecological model can be obtained, will be discussed. The modules of the spatial system are strongly connected to, and dependent from each other, however, each of them works independently, too.

The model introduced in this paper describes just an only prey-predator or plant-pest relation and is based on two assumptions:

- Populations have a great number of individuals (hypothesis of abundance).

- Individuals belonging to the same populations are identical in every dynamically relevant aspects (hypothesis of uniformity).

There is no need to consider the third assumption known in population dynamics, namely the hypothesis of ergodicity. Every individual perceives the same environment around itself. This statement is true exclusively in the homogeneous parts inside in an inhomogeneous piece of field.

An inhomogeneous piece of field was divided into $5 \times 5$ parcels and it was considered to be separately homogeneous. In all the parcels, the number of plants $(Z)$ and the number of pests $(H)$ are known. Simulate the parcels with a neighbour model. The quantities of the elements of the food chain in the different parcels are varying dynamically in time.

At the $(t+1)^{\text {th }}$ point of time, the quantity of pests in cell $i$ depends on the quantity of the nutrient available there and the number of the pests invading from the neighbourhood. There are individuals of two kinds of pests represented in the model, the first one is attacking frontally (locally), the second one attacks globally.

$$
H_{i, t+1}=\left\{H_{i} \cdot F_{i}^{w}+\sum_{j} H_{j} \cdot\left(1-F_{j}\right) \cdot Q_{i j} \cdot W_{i j}\right\}_{t},
$$


where:

$$
F_{i}=\left\{\begin{array}{cl}
\frac{1}{1+\frac{a \cdot H_{i}+b}{Z_{i}+c}} & \text { if } \frac{a \cdot H_{i}+b}{Z_{i}+c} \geq 1 \\
1 & \text { else }
\end{array} .\right.
$$

- $H_{i}$ denotes the quantity of the pests in the $i^{\text {th }}$ parcel $(\mathrm{kg})$,

- $Z_{i}$ expresses the quantity of the plants in the $i^{\text {th }}$ parcel $(\mathrm{kg})$,

- coefficient $a$ sets the proportion $\frac{a \cdot H_{i}+b}{Z_{i}+c}$ such that $F_{i}=1$ if the quantity of the plant is just enough for the pest. If the situation is unfavourable, $F_{i}<1$, while in case $F_{i}<<1$, all the pests intend to depart from the parcel. Setting coefficient $a$ is of great importance from the aspect of the model, because this factor determines principally whether a pest should abandon the parcel or the parcel is considered as suitable or even ideal to remain there.

- Parameters $b$ and $c$ are to avoid numerical errors during the calculations. They denote the quantities of the so-called 'surviving individuals' that are staying for a (short) while in cells without suitable living circumstances. It is obvious that $b<<H_{i}$ and $c<<Z_{i} / a$.

- $\quad w$ is a speed factor of compulsion to emigrate that sets the strength of will to leave a cell. With the help of this factor the pests can be characterized according to the differences in their ways of emigration. For example, some of them depart very quickly if the conditions change to a bit unfavourable, while others would If abandon the territory later, not so rapidly.

$$
\frac{a \cdot H_{i}+b}{Z_{i}+c}<1,
$$

then function $F_{i}$ takes the value of 1 . In this case the quantity of the plants is sufficient for the pests, the pests do not intend to depart from the territory. The quantity of the pests that are going to stay in the next cycle is expressed by $H_{i, t} \cdot F_{i}{ }^{w}$. It is obvious, that the greater the proportion

$$
\frac{a \cdot H_{i}+b}{Z_{i}+c}
$$

is, the closer to zero function $F_{i, t}$ is, which means that some of the pests might be going to stay in the parcel, but more of them try to abandon. If the territory is ideal $\left(F_{i}=1\right)$, they would not want to leave the parcel. By the sum

$$
\sum_{j} H_{j} \cdot\left(1-F_{i}^{w}\right) \cdot Q_{i j} \cdot W_{i j}
$$

it can be calculated, how many pests arrive from the rest of the parcels $j$ to the observed parcel $i$, where 


$$
Q_{i j}=\left(\frac{1}{\left(x_{i}-x_{j}\right)^{2}+\left(y_{i}-y_{j}\right)^{2}}\right)^{v} .
$$

- The coordinates of the examined parcel are denoted by $\left(x_{i}, y_{i}\right)$.

- The coordinates of that particular parcel, from where the pests are arriving are denoted by $\left(x_{j}, y_{j}\right)$.

- The rate of attacking ability that describes how far a pest can go is denoted by $v$. It was necessary to build this factor into the model, because the measure of infection depends greatly on the distance of the parcels. In the case $v>>1$, the attacker can be considered as the only one attacking frontally. If $v \cong 0$, the pest Finally, can appear everywhere sooner or later.

$$
W_{i j}=\frac{\frac{\left(Z_{i}+c\right)^{2}}{a \cdot H_{i}+c}}{\sum_{j} \frac{\left(Z_{j}+c\right)^{2}}{a \cdot H_{j i}+c}} .
$$

Factor $W_{i j}$ shows how „desirable” a given parcel is. If $W_{i j}$ is great, a pest would more likely go towards the parcel. It is possible, that a parcel is highly desirable, but it is too far, in this case the pests are going to choose a less favourable, but closer parcel.

\section{A case study for the spatial model}

A very simple case study, in which there are completely the same quantities of available nutrient in every parcel of the $5 \times 5$ field, is demonstrated as follows. In one of the corner parcels, there appear some pests. This sample is set for a pest with a medium emigration ability. The tables below show the changes till a stable situation is set in.

In Fig. 7 a spreading process can be seen, where 1000 pests appeared in the upper left corner. All the parcels contained 100 units of plants as aliment. The quantities of the pests are shown on the left side, graphically, on the right side, numerically. It can be seen, that the pests moved every time in the direction with the more ideal (greater) proportion of plant nutrients per pests. In the current situation the value of $a$ is set to 1 . The process of spreading will continue until the value of function $F_{i}$ reaches 1 , so the proportion

$$
\frac{a \cdot H_{i}+b}{Z_{i}+c}
$$

falls below 1 .

This model has many possibilities of progress in it. Not only the plant aliment but also the simultaneous presence of more pests and plants can be described. Even the effects of the relief can be built into this model. 
1

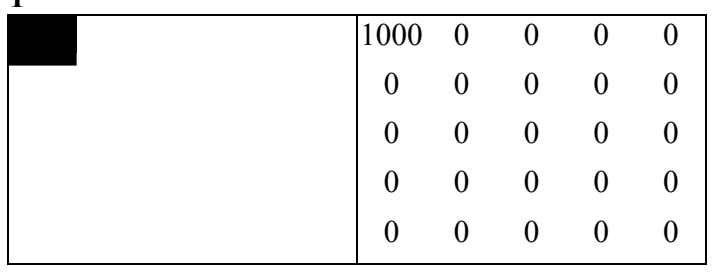

2

\begin{tabular}{|l|ccccc|}
53 & 474 & 0 & 0 & 0 \\
474 & 0 & 0 & 0 & 0 \\
0 & 0 & 0 & 0 & 0 \\
0 & 0 & 0 & 0 & 0 \\
0 & 0 & 0 & 0 & 0 \\
\hline
\end{tabular}

3

\begin{tabular}{|l|ccccc|}
\hline & 331 & 56 & 139 & 0 & 0 \\
56 & 278 & 0 & 0 & 0 \\
139 & 0 & 0 & 0 & 0 \\
0 & 0 & 0 & 0 & 0 \\
0 & 0 & 0 & 0 & 0 \\
\hline
\end{tabular}

4

\begin{tabular}{|l|ccccc|}
\hline & 59 & 267 & 78 & 20 & 0 \\
267 & 61 & 75 & 0 & 0 \\
78 & 75 & 0 & 0 & 0 \\
20 & 0 & 0 & 0 & 0 \\
0 & 0 & 0 & 0 & 0 \\
\hline
\end{tabular}

5

\begin{tabular}{|l|c|ccccc|}
\hline & 196 & 62 & 147 & 20 & 0 \\
\hline & 62 & 198 & 75 & 0 & 0 \\
147 & 75 & 0 & 0 & 0 \\
20 & 0 & 0 & 0 & 0 \\
0 & 0 & 0 & 0 & 0 \\
\hline
\end{tabular}

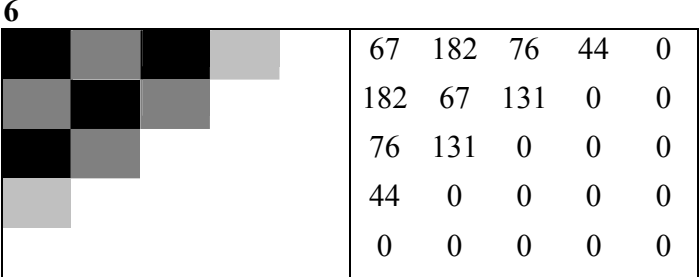

7

\begin{tabular}{|l|ccccc|}
\hline & 143 & 69 & 126 & 44 & 0 \\
69 & 167 & 81 & 12 & 0 \\
126 & 81 & 25 & 0 & 0 \\
& 44 & 12 & 0 & 0 & 0 \\
& & 0 & 0 & 0 & 0 \\
\hline
\end{tabular}

8

\begin{tabular}{|l|ccccc|}
\hline & 77 & 140 & 83 & 58 & 0 \\
140 & 71 & 119 & 12 & 0 \\
83 & 119 & 25 & 0 & 0 \\
58 & 12 & 0 & 0 & 0 \\
\hline & 0 & 0 & 0 & 0 & 0 \\
\hline
\end{tabular}

9

\begin{tabular}{|l|ccccc|}
\hline & 98 & 93 & 99 & 66 & 0 \\
93 & 98 & 97 & 23 & 0 \\
99 & 97 & 47 & 0 & 0 \\
66 & 23 & 0 & 0 & 0 \\
& 0 & 0 & 0 & 0 & 0 \\
\hline
\end{tabular}

Figure 7. Temporal-spatial quantity of pests in dates 1-9. 


\section{Application of the state-planes}

The above mentioned spatio-temporal simulation models offer new possibilities to use the multivariate state-planes. Executing the ecosystem food web model for one year, we took out data of every tenth day to obtain the reference database and to make the indirect ordination. For a simple visualisation of the state-plane we can use Excel diagrams. For a more detailed representation and further analysis of the objects (places / dates) and other related information in many point of views the use of a GIS program is recommendable. In the followings we demonstrate two case studies, which simulate the temporal changes of different parcels in an inhomogeneous field.

\section{The effects of different nutrient amounts}

The amount of the available nutrients can significantly influence the states of an agro-ecosystem. In Fig. 8, we can examine it in a simulated situation. The simulation shows the results of parcels with different available nutrients at the same period in spring and at the beginning of summer. The moderate and high nutrient levels come from an additional nutrient dosage after 15 days of the simulation, so the three trajectories have the same origin.

In the figure we can see that the trajectories more and more differ from each other. As the nutrient amount is increasing, the trajectories go to the left and down. We know from other results that this area means the better conditions for the cultivated plant. The observed changes in the states help the impact assessment of fertilizing.

\section{The effect of different plant protection methods}

Similarly to the fertilizing the different plant protection methods can be considered as agrotechnical treatments. In this case we simulated the use of pesticides decreasing the density of the affected populations on a given day. All other parameters kept their values. M1 means a selective insect control against a monophagous pest, the other treatment was a general zoocide (Fig. 9). In this case the changes are not continuous as in the former example, steps from a point to the other can be observed in accordance with our expectation. The results change in the same direction, but with different rates. Of course, the general zoocide, which effects all the four insect populations, proved to be most drastic, compared with the original state. In both examples we can observe that the trajectories are similar to a pipe. This shape comes from the seasonal dynamics (Hufnagel and Gaál [38]), which proved to be a very strong effect.

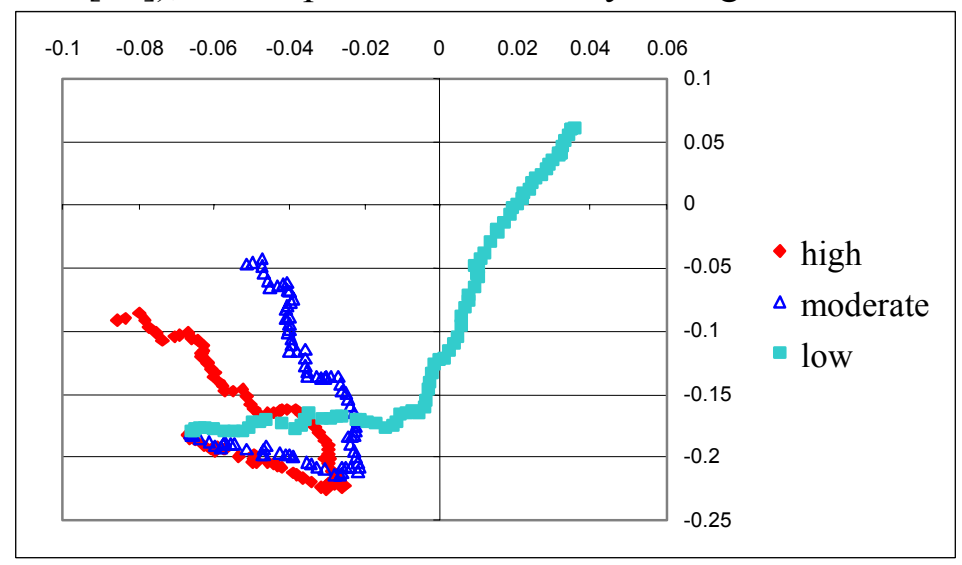

Figure 8. The effects of different nutrient amounts. 


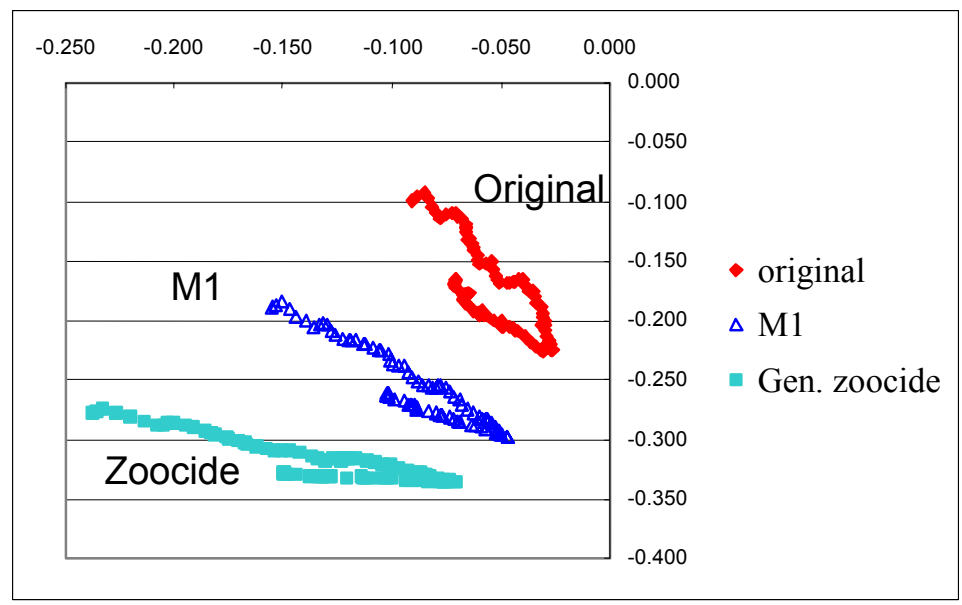

Figure 9. The effect of different plant protection methods

\section{Discussion}

(1) During the simulation of the food web model the effects of some extremal events were examined, as well, such as the extinction of a population that might cause the extinction of the monophagous that consumes it. Our further plans are the surveys of the exhaustion of soil, the manual intervention like fertilization, plant protection, watering, ploughing, sowing, harvesting (e.g. in Hufnagel and Gaál [38]), the longterm time series the risk and stability analysis of the above effects, the effect of extreme weather conditions and global change. The models are intended to be generalized for highly complex food web systems with great volumen populations and to extend and validate them for special food web systems.

(2) The phenology model that was introduced above was created originally with the following aims:

- To switch on/off certain elements of the food web model [53] that describes the biomass dynamics of populations in an ecosystem. In this way, the seasonal changes of both biotic and abiotic interactions of the examined individual can be followed more exactly.

- To convert the measure of biomass for the number of individuals. In this way, the reasons of biomass change can be seen well.

- Above all, a methodical development of the general model was intended to give through an example for pest populations. The model can be embedded in simulation models with discrete difference equations. Similar models in literature have probably not yet been appeared.

The phenology model can be applied in studies of phenological events of pests even independently of the food web model. In addition to in modelling ecosystems, it is expected to be applied in plant protection prognostics as well to improve the phenology model, further investigations are planned, such as:

- a stochastic generalization,

- a spatial generalization $[29,30,73]$,

- an application for pest populations with different phenologies,

- a validation and fitting for real data, 
- an investigation of the validated model for quite different weather conditions,

- a study of the effects of extreme weather conditions and global change.

The systems presented in this paper are used for modelling the spatio-temporal patterns of agricultural ecosystems. The joint application of the simulation models and the state-planes could help us to survey the effects of the ecological and agrotechnical conditions in the same system. If we can fit our model to real field monitoring data, too, a wider range of interpretations and conclusions will be obtained. In this case the reference database, itself, should contain both real and simulated data that can generalize the application possibilities of the state-plane systems.

Based on the case studies, our systems seem to be suitable to solve the problems mentioned in the introduction, so the systems are still under development.

Acknowledgements. We would like to express our thanks to Professor Zs. Harnos for supporting our work at Szent István University, Department of Mathematcs and Informatics.

\section{REFERENCES}

[1] Bartha, S., Czárán, T. \& Oborny, B. (1996): Spatial constraints masking community assembly rules: A simulation study. - Folia Geobot. Phytotax. Praha 30: 471-482.

[2] Bechini, L., Bocchi, S. \& Maggiore, T. (1999): Spatial interpolation of soil properties for irrigation planning. A case study in Nothern Italy. Proc. of the 1st International Symposium Modelling Cropping Systems, Lleida, Spain, pp. 143-144.

[3] Berti, A., Morari, F., Borin, M. \& Giardini, L. (2001): Use of CropSyst to simulate a four-year rotation with different fertilization levels. - Proc. of the 2nd International Symposium Modelling Cropping Systems, Florence, Italy, pp. 51-52.

[4] Bíró, J. \& Hufnagel, L. (2001): Bioindikáció Heteroptera közösségek alapján a Balaton vízrendszerében. - Hidrológiai Közlöny 81(5-6): 339-341.

[5] Beven et al. (1994): TOPMODEL and GRIDATB. Centre for Research on Environmental Systems and statistics. Technical Report TR 110/94. Lancaster University, Lancaster, UK.

[6] Bouman, B.A.M. (1992): SBFLEVO and WWFLEVO, Growth models to simulate crop growth, optical reflectance and radar backscatter of sugar beet and winter wheat, calibrated for Flevoland. CABO-DLO report 163. CABO-DLO Wageningen, The Netherlands, $116 \mathrm{pp}$.

[7] Bouman, B.A.M. (1993): ORYZA_W, Rice growth model for irrigated and water limited conditions. SARP report, AB-DLO, $67 \mathrm{pp}$.

[8] Chen, S., Zhao, B., Stockle, C.O., Harrison, J. \& Nelson, R. (2002): Use of models as decision support tools in dairy nutrient management. ASAE Paper No. 02-4094, St. Joseph, MI.

[9] Chertov, O.G. \& Komarov, A.S. (1995): On mathematical theory of soil forming processes. 1. Theoretical background. 2. SOMM - a model of soil organic matter dynamics. 3. Basic ideas of a mineral phase modelling. Russian Academy of Sciences. Pushino Research Center. Institute of Soil Science \& Photosynthesis. Preprint, 41 pp.

[10] Crisci, A., Moonen, C., Ercoli, L. \& Bindi, M. (2001): Study of the impact of climate change on wheat and sunflower yields using a historical weather data-set and a crop simulation model. - Proc. of the 2nd International Symposium Modelling Cropping Systems, Florence, Italy, pp. 119-120.

[11] Czárán, T. (1998): Populáció- és társulásdinamika térben és időben: tömeg- és objektumkölcsönhatási modellek. - In: Fekete, G. (ed.) A közösségi ökológia frontvonalai. Scientia, Budapest, pp. 35-58. 
[12] Csörgits, G. \& Hufnagel, L. (2000): Heteroptera fajegyüttesek a Dunán. - Hidrológiai Közlöny 80(5-6): 288-290.

[13] Csörgits, G. \& Hufnagel, L. (2000): Heteroptera és Odonata fajegyüttesek a Nyéki-HoltDuna hínár állományaiban. - Hidrológiai Közlöny 80(5-6): 291-294.

[14] Donatelli, M., Spallacci, P., Marchetti, R. \& Rapini, R. (1996): Evaluation os CropSyst simulations of growth of maize and water balance and soil nitrate content following organic and mineral fertilization applied to maize. - 4th European society for Agronomy Congress, Veldhoven-Wageningen, The Netherlands, pp. 342-343.

[15] Erdélyi, É. (2002): A növények által hasznosítható tápanyagmennyiség időbeli változásának modellezése. - 6. Magyar Biometriai és Biomatematikai Konferencia, SZIE ÁOK, pp.18-19.

[16] Ferenczy, A., Hufnagel, L., Pécs, M. \& Mészáros, Z. (1999): Biodiverzitás monitorozás a növényvédelmi fénycsapdahálózat adatai alapján. - 5. Magyar Biometriai és Biomatematikai Konferencia, BDTF, Szombathely, pp. 79-80.

[17] Francaviglia, R. \& Marchetti, D. (1999): Comparison of cropping systems models in the simulation of crop biomass and grean leaf area index development. - 1st International Symposium Modelling Cropping Systems, Lleida, Spain, pp. 181-182.

[18] Gabrielle B., Menassari, S. \& Houot, S. (1995): Analysis and field evaluation of the CERES models' water balance component. - Soil science Society of America Journal.

[19] Gaál, M. (1997a): Az informatika eszközeinek felhasználása a kertészetben. - Új Kertgazdaság, 1997(4): 54-57.

[20] Gaál, M. (1997b): Az informatika alkalmazási lehetőségei a zöldségtermesztésben. MTA kandidátusi értekezés, Kertészeti és Élelmiszeripari Egyetem, Budapest.

[21] Gaál, M. (1998): Ökológiai alapú szaktanácsadási információs rendszer. - Gazdálkodás, 42(1): 50-57.

[22] Gaál, M. \& Hufnagel, L. (1999): Vízi élőhelyek állapotának monitorozása poloskaközösségek alapján. - Agrárinformatika 1999, DAE, Debrecen, pp. 346-350.

[23] Gaál, M. \& Hufnagel, L. (2000): Új módszerek az alkalmazott rovartani monitorozásban. - Lippay János-Vas Károly Tudományos Ülésszak, Növényvédelmi Szekció, SZIE, Budapest, pp. 382-383.

[24] Gaál, M. \& Hufnagel, L. (2001): Combination of Multivariate Methods and Graphical Database Management in Service of Ecological Monitoring. - 3rd EFITA 2001 (vol 1), agroMontpellier ENSA, Montpellier, pp. 285-290.

[25] Giardini, L., Berti, A. \& Morari, F. (1998): Simulation of two cropping systems with EPIC and CropSyst models. - Ital. J. Agron. 1: 29-38.

[26] Godwin, D.C. \& Meyer, W.S. (1995): Balancing crop production with salinity and watertable management. - 2nd International Symposium on Systems Approaches for Agricultural Development, Los Banos, Phillippines.

[27] Hansen, S., Jensen, H.E., Nielsen, N.E. \& Svendsen, H. (1990): DAISY - Soil Plant Atmosphere System Model. NPo-forskning fra Miljostyrelsen Nr. A10, 272 pp.

[28] Harnos, Zs. (1991): Az alkalmazkodó mezőgazdaság rendszere: módszertani kutatások. KÉE, Budapest.

[29] Horváth L.. (2002): Térbeli inhomogenitások kezelésének módszertani problémái a precíziós növénytermesztésben. [Spatial inhomogenity problems in precision farming.] Szimuláció és monitoring az agrárökoszisztémák vizsgálatában IV., Agrárinformatika 2002 (Debrecen, 2002. aug. 27-28.), pp. 335-343.

[30] Horváth, L. Gaál, M. \& Hufnagel, L. (2003): Modelling of spatio-temporal patterns of ecosystems in agricultural fields - Proceeding of EFITA 2003, Debrecen, Hungary, pp. 882-889.

[31] Hufnagel, L. (in press) Modellezés a populációdinamikában. Szemináriumi kötet, SZIE, Budapest. 
[32] Hufnagel, L., Mészáros, Z., Gaál, M. \& Ferenczy, A. (1999): Temporal spatial patterns of Noctuinae communities in Hungarian apple orchards. - Acta Phytopathologia et Entomologia Hungarica 34(4): 341-351.

[33] Hufnagel, L., Bakonyi, G. \& Vásárhelyi, T. (1999): New approach for habitat characterization based on species list of aquatic and semiaquatic bugs. - Environmental Monitoring and Assessment 58: 305-316.

[34] Hufnagel, L., Bakonyi, G. \& Vásárhelyi, T. (1999): Sokváltozós módszerek alkalmazása vízi és vízfelszíni poloskákra épülő vízminősítési rendszerekben. - Állattani Közlemények 84: $29-41$.

[35] Hufnagel, L., Gaál, M., Ferenczy, A. \& Öszi, B. (1999): Többváltozós módszerek alkalmazása rovaregyüttesek tér-időbeli zoocönológiai monitorozásában. - Informatika a felsőoktatásban 1999 DESZ, Debrecen, pp. 215-220.

[36] Hufnagel, L. \& Stollmayer, B.E. (1999): Zoocoenological pattern of bug assemblies in the Szilas and Gyáli streams. - Opuscula Zoologica 31: 69-77.

[37] Hufnagel, L., Gaál, M., Öszi, B. \& Mészáros, Z. (2001): Population dynamical stability in service of plant protectional prognosis. - Acta Phytopathologia et Entomologia Hungarica 36: 93-99.

[38] Hufnagel, L. \& Gaál, M. (2002): Többváltozós állapotsík-rendszerek alkalmazása valósés szimulált adatsorok kezelésében. [Multivariate state-planes in service of analysis of field- and simulated data.] - Szimuláció és monitoring az agrárökoszisztémák vizsgálatában II., Agrárinformatika 2002 (Debrecen, 2002. aug. 27-28.), pp. 315-325.

[39] Jermy, T. \& Szelényi, G. (1958): Az öszi búza állattársulásai. - Állattani Közlemények 46: 229-241.

[40] Jordán, F. (1998): A táplálékhálózatok szerkezete. - Természet Világa 129(6): 254-257.

[41] Jordán, F. (2000): Seasonal changes in the positional importance of components in the trophic flow network of the Chesapeake Bay. - Journal of Marine Systems, 27:289-300.

[42] Jordán, F. (2001): Rejtett fajkölcsönhatások. - Természet Világa 132(3): 98-101.

[43] Jordán, F. \& Molnár, I. (1999): Reliable flows and preferred patterns in food webs. Evol. Ecol. Res. 1: 591-609.

[44] Jordán, F., Takács-Sánta, A. \& Molnár, I. (1999): A reliability theoretical quest for keystones. - Oikos 86: 453-462.

[45] Kabat, P., Broek, B.J. van den \& Feddes, E.A. (1992): SWACROP: A Water Management and Crop Production Simulation Model. - ICID Bulletin 41(2): 61-84.

[46] Keulen, H. van \& Seligman, N.G (1987): Simulation of water use, nitrogen nutrition and growth of a spring wheat crop. - Simulation Monographs, Pudoc-DLO, Wageningen, The Netherlands, $308 \mathrm{pp}$.

[47] Knisel, W.G. (ed.) (1980): CREAMS: A Field Scale Model for Chemicals, Runoff, and Erosion from Agricultural Management Systems. - USA Dept. of Agriculture, Conservation Research Report No. 26.

[48] Kropff, M.J. \& Laar, H.H. van (eds.) (1993): Modelling crop-weed interactions. Wallingford: CAB International, $274 \mathrm{pp}$.

[49] Laar, H.H. van, Goudriaan, J., Keulen, H. van (eds.) (1992): Simulation of crop growth for potential and water limited production situations, as applied to spring wheat. Simulation Reports 27, $72 \mathrm{pp}$.

[50] Ladányi, M. (2002): Egy táplálékhálózat populációdinamikai modellje. - 6. Magyar Biometriai és Biomatematikai Konferencia, SZIE ÁOK, Budapest, pp. 43-44.

[51] Ladányi, M.,-Hufnagel, L. (2003): A Phenology Model embedded in an Ecosystem Model for Agroecological Processes - Proceedings of EFITA 2003, Debrecen, Hungary, pp.876-881.

[52] Ladányi, M., Erdélyi, É. \& Révész, A. (2003): An Ecosystem Model to Simulate Agroecological Processes. - Proceedings of EFITA 2003, Debrecen, Hungary, pp. 739746. 
[53] Ladányi M. \& Erdélyi É. (2002): Kölcsönhatási hálózatok időbeli szimulációja. [A seasonal population dynamical model of a food-web.] - Szimuláció és monitoring az agrárökoszisztémák vizsgálatában I., Agrárinformatika 2002 (Debrecen, 2002. aug. 2728.), pp. 315-325.

[54] Lindeman, R.L. (1942): The trophic-dynamic aspect of ecology. - Ecology 23: 399-417.

[55] Levin, S. A. (1978): Population dynamic models in heterogenous environments. - Ann. Rev. Ecol. Syst. 7: 287-310.

[56] Loveland, P.J., Rounsevell, M., Legros, J.P., Rosa, D. de la, Armstrong, A., Glinski, J., Rajkai, K., Simota, C. (eds.) (1995): ACCESS. Agro-Climatic Change and European Soil Suitability: a spatially distributed, soil, agro-climatic and soil hydrological model to predict the effects of climate change on land-use within the European Community. Volume II: user manual. $62 \mathrm{pp}$.

[57] Martorana, F. \& Bellocchi, G. (1999): A review of methodologies to evaluate agroecosystem symulation models. - Ital. J. Agron. 3: 19-39.

[58] Mols, P.J.M. (1990): Forecasting orchard pests for adequate timing of control measures. Proc. Exp. \& Appl. Entomol., Vol. 1, NEV, Amsterdam, pp. 75-81.

[59] Mols, P.J.M. (1992): Forecasting an indispensable port of IBM in apple orchards. - Acta Phytopatologica Entomologica Hungarica 27(1-4): 449-460.

[60] Monaco, S., Sacco, D. \& Grignani, C. (2002): Analysis of the influence of different environmental factors in crop growth. - VII. European Society for Agronomy Congress, Cordoba, Spain, pp. 303-304.

[61] Murray, J. D. (1989): Mathematical biology. Springer Verlag, New York.

[62] Novak, V. \& Majercak, J. (1992): Simulation of the soil-water dynamocs in the root zone during the vegetation period. II. The course of state variable of soil water below maize canopy. - Journal of Hydrology and Hydromechanics 40: 380-397.

[63] Nováky, E. (1990): Prognosztizálás, tervezés, modellezés a környezetvédelemben. Aqua Kiadó, Budapest.

[64] Nyilas, L. Hufnagel, L., Gaál, M. \& Mészáros, Z. (2000): Seasonal and successive dynamics of Noctuidae assemblies based on light trap collections in Julianna Major. Proceedings of the Lippay János \& Vas Károly Scientific Symposium (6-7. Nov. 2000, Budapest), pp. 426-427.

[65] Okubo, A. (1980): Diffusion and Ecological Problems: Mathematical Models. Biomathematics, Vol. 10. Springer Verlag, Berlin, Heidelberg, New York.

[66] Otten, W. (1994): Dynamics of water and nutrients for potted plants induced by flooded bench fertigation: experiments and simulation. Thesis. Wageningen, $115 \mathrm{pp}$.

[67] Pimm, S.L. (1982): Food Webs. Chapman and Hall, London.

[68] Pimm, S.L., Lawton, J.H. \& Cohen, J.E. (1991): Food web patterns and their consequences. - Nature 350: 669-674.

[69] Podani, J. (1993): SYN-TAX Computer programs for multivariate data analysis in ecology and systhematics. - Abstracta Botanica 17(1-2): 289-302.

[70] Podani, J. (1994): Multivariate analysis in ecology and systhematics. SPB Publishing, The Hague.

[71] Podani, J. (1997): Bevezetés a többváltozós biológiai adatfeltárás rejtelmeibe. Scientia, Budapest.

[72] Révész, A. \& Horváth, L. (2002): A fenológiai prognózis új módszerei 6. - Magyar Biometriai és Biomatematikai Konferencia, Budapest.

[73] Révész, A. (2002): Új lehetőségek az empírikus hőösszeg modellezésben. [New options for empirical heat-unit modelling.] - Szimuláció és monitoring az agrárökoszisztémák vizsgálatában III., Agrárinformatika 2002 (Debrecen, 2002. aug. 27-28.), pp. 326-334.

[74] Scheuring, I., Jánosi, I.M., Csilling, Á. \& Pásztor, G. (1993): SOC defeats chaos: A new population dynamical model. - In: Novak, M.M. (ed.): Proceedings of the IFIP Second International Conference on Fractals in the Natural and Applied Sciences. London, Amsterdam. 
[75] Silvestri, N., Bellocchi, G., Mazzoncini, M. \& Menini, S. (1999): Evaluation of the CropSyst model for simulating soil water, soil nitrate, green area index and above-ground biomass of maize under different management. - 1st International Symposium Modelling Cropping Systems, Lleida, Spain, pp. 253-254.

[76] Stöckle, C.O., Donatelli, M. \& Nelson, R. (2003): CropSyst, a cropping systems simulation model. - Eur. J. Agron. 18: 289-307.

[77] Svendsen, H., Hansen, S. \& Jensen, H.E. (1995): Simulation of crop production, water and nitrogen balances in two german agro-ecosystems using the daisy model. - Accepted in Modelling of geo-biosphere Processes.

[78] Szász, G. (1988): Agrometeorológia - általános és speciális. Mezőgazdasági Kiadó, Budapest.

[79] Ulanowicz, R.E. (1983): Identifying the structure of cycling in ecosystems. - Math. Biosci. 65: 219-237.

[80] Ulanowicz, R.E.,- Wolf, W.F. (1991): Ecosystem flow networks: loaded dice, Math. Biosci. 103: 45-68.

[81] Varga, I. \& Hufnagel, L. (2001): Temporal-spatial patterns of aquatic and semiaquatic Heteroptera at Lake Fertő. - Opuscula Zoologica 33: 99-112.

[82] Verberne, E.L.J., Hassink, J., Willigen, P. de, Groot, J.J.R. \& Veen, J.A. van (1990): Modelling organic matter dynamics in different soils. - Netherlands Journal of Agricultural Science 38: 221-238.

[83] Watt, A. S. (1947): Pattern and process in the plant community. - J. Ecol. 35: 1-22.

[84] Wilson, J. B. (1994): Who makes the assembly rules? - J. Veg. Sci. 5: 275-78. 